\author{
Asian Journal of Economic Modelling \\ $\operatorname{ISSN}(e): \quad 2312-3656$ \\ $\operatorname{ISSN}(p): \quad 2313-2884$ \\ DOI: $10.18488 /$ journal.8.2014.23.115.127 \\ Vol. 2, No. 3, 115-127 \\ (C) 2014 AESS Publications. All Rights Reserved. \\ URL: www.aessweb.com
}

\title{
TRENDS AND DRIVERS OF AGRICULTURAL INVESTMENTS AND GROWTH IN NIGERIA: THE PRE AND FINANCIAL SECTOR REFORMS EXPERIENCE
}

\author{
Akpaeti, Aniekan $\mathbf{J}^{1}$ \\ Bassey, Nsikan $\mathrm{E}^{2}$ \\ Okoro, Udeme $\mathbf{S}^{3}$ \\ Nkeme, Kesit $\mathbf{K}^{4}$
}

\author{
${ }^{1,2,3,4}$ Department of Agricultural Economics and Extension, Akwa Ibom State \\ University, Ikot Akpaden, Mkpat Enin, Uyo, Akwa Ibom State, Nigeria \\ (+ Corresponding author)
}

\section{Keywords \\ Trend \\ Drivers \\ Agricultural investments \\ Growth.}

\section{ABSTRACT}

This study examined the growth rates in agricultural investments and output in Nigeria from 1970-2009 using ordinary least square in a time series analysis. Findings revealed that agricultural investments and growth recorded a growth rate of 37.44 percent and 30.47 percent in the pre-financial sector reform periods. The result for the financial sector reform periods showed a growth rate of 23.00 percent and 7.04 percent for agricultural investment and growth respectively. The differences in growth rates were not significantly different at 5 percent $\left(\mathrm{t}_{\mathrm{cal}}<\mathrm{t}_{\mathrm{tab}}\right.$ at $\left.\mathrm{P}=0.5\right)$ between the periods. There was also deceleration in growth of agricultural investments in the two periods under consideration, implying that financial sector reform might have brought an overall decrease in agricultural investments in the two periods. Also, while there was stagnation in the growth process of agricultural output in the pre-financial sector reform periods, there was acceleration in the financial sector reform periods. Hence, policies and sound regulatory framework that would enhance the development of a strong, healthy and dynamic financial system should be pursued. Such policies should be tailored towards the provision of sound infrastructures and macroeconomic stability that would create incentives for agricultural investment and growth of business opportunities on a sustainable basis and foster the expansion of financial institutions.

Contribution/ Originality: The study identified the financial sector as a principal driver of agricultural investment and growth with a long-run relationship between them. It has also revealed that the financial sector reform had no significant impact on agricultural investment and growth in Nigeria thus, contributing to existing literature on similar work. 


\section{INTRODUCTION}

One of the greatest challenges facing the Nigerian economy is reducing poverty incidence to the barest minimum given the increasing population growth rates in developing countries. In 2004, approximately 69 million people, or 54 percent of the Nigerian population, lived below the poverty line (Diao et al., 2010). This situation calls for the prioritizing of the agricultural sector in government development and poverty reduction efforts. Agricultural sector has been a key driver of recent economic growth in Nigeria, accounting for 70 percent of GDP of the non-oil sector (Mang, 2009) and providing subsistence for $2 / 3$ of Nigerians who are low income earners (Usman, 2006). It is the single most important sector in Nigeria and some other African countries, providing livelihood for at least 53 percent of the economically active labour force (Food and Agricultural Organisation, 2000)

The 2005 Appropriation Bill presented to the National Assembly, projected the Nigerian economy to grow at the rate of 7 percent over the fiscal year. As evidenced in the bill, much of the expected growth of the economy was to be derived from growth in agricultural sector. This situation brings into focus the level of agricultural investments required to sustain the projected growth given that, Nigerian agriculture consist of large numbers of smallholder farmers, scattered across the Country (Nwosu, 2004). Undoubtedly, agricultural production in Nigeria is dominated by small-scale farmers characterized by small, uneconomic and often fragmented holdings that make use of simple implements and unimproved planting materials for farming. The attendant economic plight of these small household farmers has been aptly described as a vicious web of low productivity in output, income and capital investment. This self-perpetuating web is said to inhibit the participation of the traditional farmers in economic development (Nwosu and Ogunfowora, 1977). This in addition to poor funding and access to finance renders the sector unproductive. Therefore, for traditional agriculture to break out of this vicious cycle there is need for massive injection of capital from outside the farming system as well as encouraging organized private sector participation. It is obvious that government alone cannot provide all the funds required to cause traditional agriculture to break out of the low capital investment and low productivity -syndrome. To address this, financial stakeholders have greater roles to play in providing funds for agricultural investment as well as other relevant supports that would spur the desired growth in the sector.

However, in recent years, successive government in Nigeria in attempt to promote investment and growth has formulated several policies prominent among which are: the National Economic Empowerment and Development Strategies (NEEDS) I and II, the Comprehensive Africa Agriculture Development Program (CAADP), the National Food Security Program (NSFP), as well as other Presidential initiatives tailored towards boosting the output of preferred crops such as cassava and rice. Diao et al. (2010) attributed the increase in annual agricultural growth rate from 3.5 percent in 1990-1999 periods to 5.9 percent in 2000-2007 periods to the aforementioned policies of the government. In addition these policies, (Central Bank of Nigeria, 2004) posited that a high level of capital accumulation, with the right combination of the other factors of production is capable of bringing about higher output growth rates in the sector. Interestingly, capital accumulation alone, without appropriate human capital, policies and 
conducive macroeconomic environment may not lead to economic growth. It is against this backdrop that this study examines the trend and drivers of agricultural investments and growth in Nigeria. Specifically, the study would evaluate the growth rates in agricultural investments and output in the pre-reforms (1970-1986) and reforms period (1987-2009). It would also investigate the existence of acceleration, deceleration or stagnation in growth rates of agricultural investments and output in Nigeria respectively.

\section{THEORETICAL AND EMPIRICAL LINKS BETWEEN INVESTMENT AND GROWTH}

The theoretical relationship between investment and growth has been well articulated in literature. The production function formulation and the Harrod-Domar model coupled with the works of early development economists such as Rosentein-Rodan, Ragnar Nurkse, Arthur Lewis to mention but a few, attributed a vital role to capital formation, especially infrastructure, in the growth process. However, in 1960s and 1970s, the neoclassical growth theorists of that time opposed the active part played by investment in the growth process. Robert Solow's model indicates that capital accumulation affects growth only during the transition to the steady state and that long-term growth is determined only by the rate of technical change, which is assumed to be exogenous. The endogenous growth theory of Romer (1986) and others further stress the insufficiency of capital accumulation to guarantee long-term growth. The new theorists argue that sustained growth depends not only on accumulation of physical capital, but on two fundamental ingredients: human capital and technical knowledge.

Furthermore, the non-neoclassical theorists gave a divergent view to the theoretical proposition of the neoclassical theorists. This led to the reawakening of interest in the active part played by investment in the growth process. They argued that existing relationship between investment and growth is dynamic and go beyond the mere productivity-capital intensity relationship that results from an organized production. This implies that investment is not only to increase a factor of production but is a means of implementing new technologies and techniques. In this context, it explained why eventual decreasing returns should set in with high rates of investment since technical change is regarded as being "embodied" in new capital goods. This contradicts the neoclassical argument. As such, high rates of investment lead to faster technical progress, greater leaning-by-doing, greater learning-by-using, improved workers' skills, increase in human capital through cumulative causation to a virtuous circle of greater competitiveness and faster economic growth (De Long and Summers, 1993; Haque, 1995; Singh, 1996). Apart from the supply -side benefits highlighted above, the demand-side is equally necessary given the inter-sectoral linkages. This indicates that investment in one sector stimulates investments in the others and encourages technical and technological advancement. The contrary argument to the above (that is correlation moving from growth to investment) has also been presented in the literature (Serven and Solimano, 1993). The sensitivity of investment to cyclical variations in output (or other short-term factors) suggests that a short-term recession may have long-term effects by causing a deep investment slump that permanently traps the economy in a low-growth, low-investment equilibrium. This implies that the growth process may 
be path-dependent. Therefore, theoretically, the relationship between investment and growth is bidirectional.

Empirically, studies on agricultural investment and growth trends in Nigeria are scanty. Marjit (2004) in his study on financial sector reform for stimulating investment and economic growth- the Indian experience reported that in the pre-reform period (1980-1990), average rate of public investment dropped from 10 percent to 7.50 percent in the post 90 s, while the average private investment rate increased from 12 percent to 16 percent. In a related research, Asamoah (2008) documented that during the post-independence financial sector reforms in Ghana, per capita income growth rate averaged 1.80 percent, despite the adverse development due to poor agricultural output in 1990 and it declined to 1.0 percent on average between 1992 and 2000 . He pointed out that there were several obstacles and restrictions served to undermine private sector confidence, which warranted the need for financial sector reforms. Inflation rate shows the same pattern between 1984 and 1991 . The inflation rate was moderate hitting as low as 18 percent in 1991. It later accelerated with an average of 59.50 percent in 1995 , which was the peak before declining to 30 percent in 1997 after the central bank intervened in the foreign market to control depreciation of the exchange rate.

On the reform period in Nigeria, (Soyibo and Adekanye, 1992) opine that the rate of real resource mobilization declined. The savings/GDP ratio dropped from 15.40 percent to 12.40 percent in 1987 to 1992 . The growth of real savings also slowed down by 7.50 percent points. These developments are in harmony with the econometric evidence. The decline in real wage income during the reform could have also contributed to the fall in real savings. For instance, the index of real wage income for the middle level public service cadre declined from 100 in 1987 to 10 in 1990 and 34 in 1992. It was only in the rural areas that the expected increase in financial savings was achieved during the financial sector reforms. This was measured by the share of total deposits mobilized in the rural banks with the rural savings increased from 1.90 percent before the reform to 10.80 percent. These trends knock-off the role of community banks and the people's bank in rural credit mobilization. However, in the first years of the reforms, the share of banking system's credit to the private sector improved and superseded the flows to government for the first time in five years. Later, government's reliance on the Central Bank's financing for the soaring deficits overturned the table to its favour and the share of the private sector before the reform decrease from 50.70 percent in the total credit to 49.70 percent after the reform while in 1993 and 1994, only 34 percent of the total credit went to the private sector. The bulk of the credit that was channeled to private sector was mainly directed towards short-term investment. Between 1987 and 1994, 50 percent of the private sector fund was in the form of call money, 32.50 percent went to lending maturity within 12 months; 12 percent for 1-5 years maturity (medium-Term) and only 4.80 percent for long-term commitments exceeding five years (Emenuga, 1996).

Consequently, the above situations have not changed even in recent times in the country as Central Bank of Nigeria (Central Bank of Nigeria, 2010) reported that the annual growth rate of agriculture dropped from 55.2 per cent in 2002 to 7.4 per cent in 2006 and further declined to 6.2 per cent by the end of 2009. On the contrary, African Economic Outlook (2011) submitted that 
the Nigeria agricultural sector has performed remarkably well, with an estimated growth rate in 2010 exceeding 6.0 per cent, reflecting the good weather conditions that boosted crop production. According to Kolawole (2013), this remarkable performance was made possible by the government's effort to address protracted issues of inadequate credit and Scheme (CACS) which has benefited agricultural expansion in 2009/2010 through the provision of $\$ 200$ billion naira (Nigerian currency) at low interest rates to farmers and other practitioners in the agricultural sector. Akpaeti et al. (2013) in their works econometric assessment of trend in loanable funds in Nigeria show that the growth rate (43.76 percent) of loanable funds in the pre-financial reforms period was higher than 23.49 percent growth rate in the financial sector reforms period though was not statistically different at 5 percent while Akpaeti et al. (2014) in their works on trend evaluation of agricultural export crops in Nigeria revealed that growth rates in export of these crops are higher in the financial sector reform period than in the pre-financial sector reform period except in palm kernel and are statistically significant at 5 percent probability level.

Obadan and Odusola (2001) in their work on savings, investment and growth patterns in developing countries reported that growth performance of the four High Performing East Asian Economies (HPAES) namely, Indonesia, Malaysia, Philippines and Thailand was better than that of the selected Organization for Cooperation and Development Countries (OECD) countries between 1990 to 1998. However, while there are significant variations in the regional performances, on the whole, developing economies have tended to lag behind the advanced economies since 1960 . More than $70 \%$ of these countries grew at a slower rate than the average for the economies of the OECD countries. More disturbingly, as the World Bank (1993) has pointed out that of 118 economies surveyed for the periods 1960-70 and 1970-85, per capita income actually fell in 13 developing countries. On the other hand, 11 highest performing economies came from the Northeastern part of Asia. Evidence from the World Bank shows that 'Sub-Saharan African countries are the worst hit, relative to the Latin America and Asia countries selected from OCED. This is a clear case of high-level lopsidedness in income distribution and endemic poverty, which was also lent credence to by World Bank (1993; 1998). Klenow and Rodriguez-Clare (1997) concluded that Singapore's high growth of output per worker is a consequence of technological progress, rather than consequence of a sustainable increase in capital stock per se.

\section{MATERIALS AND METHODS}

\subsection{Data Collection}

The study made use of data from secondary sources obtained from Central Bank of Nigeria (CBN), Statistical Bulletin, Annual Report and Statements of Account of Central Bank of Nigeria (CBN) and National Bureau of Statistics (NBS). The data covered the period of 1970-2009.

\subsection{Analytical Techniques}

Data collected were analyzed using descriptive statistics such as: mean and simple percentages. Other inferential statistics used to buttress the result were: 
(i). Unit root test: To ensure that the results obtained was not spurious (Maddala, 2002), a unit root test was carried out using two specifications of the Augmented Dickey Fuller (ADF) test (i) intercept (ii) trend and intercept. This was to determine for the presence of a unit root in each of the variables (an indication of stationality). The ADF test function was to reduce autocorrelation in the error term. The test formula for ADF is shown as:

$$
\Delta Y t=\alpha+\zeta Y t-1+\sum_{t-1}^{j} \mathrm{Y} \Delta \mathrm{Y} t-j+U t .
$$

Here the lag length $\mathrm{j}$ chosen for ADF ensures $\mathrm{U}_{t}$ is empirical white noise. The importance significance of $\zeta$ is tested against the null that $\zeta=0$ based on the $t$ statistics obtained from the Ordinary Least Square estimated. If the null hypothesis of non-stationarity is not rejected, the variables are different until they become stationary.

(ii). Cointegration Test: This was employed to confirm the presence of a long-run relationship. To achieve this, the Trace and the Maximum Eigenvalue statistics of the Maximum Likelihood method (ML) developed by Johansen $(1988 ; 1991)$ was utilized. The null hypothesis for the trace test was that there are at most $r$ cointegrating vectors while for the Max Eigenvalue test, the null of $r=0$ was tested against the alternative that $r=1 ; r=1$ was tested against the alternative that $r=2$ and so on. The Schwarz Information Criterion (SIC) was used to select the optimal lag length for the cointegration test.

(iii). Ordinary Least Square (OLS) Test: OLS procedure was conducted in a time trend analysis. Growth rates were computed by fitting exponential function in time to the data following (Onyenweaku and Okoye, 2005); Okoye et al. (2008); Akpaeti et al. (2013); Akpaeti et al. (2014). The function is specified as follows:

$\mathrm{Q}=\mathrm{b}_{\mathrm{o}} \mathrm{e}^{\mathrm{bt}}$

Linearizing the equation in logarithms, it becomes

$\operatorname{In} Q=b_{0}+b_{1} t$

Where,

$Q=$ Agricultural Investments and Output growth

$\mathrm{b}_{0}=$ Intercept

$\mathrm{b}_{1}=$ Slope $($ regression parameters estimated)

$\mathrm{t}=$ Time trend Variable (Years in number)

The equation (iii) was fitted to the value of agricultural investments and output growth for two periods namely: pre-financial sector reforms (1970-1986) and financial sector reforms (19872009). The coefficients from equation (iii) were used to derive the growth rate ( $r$ ) as specified by Onyenweaku and Okoye (2005); Akpaeti et al. (2013) as follow:

$\mathrm{r}=\left(\mathrm{e}^{\mathrm{b}}-1\right) \times 100 / 1$ (Onyenweaku and Okoye, 2005); Akpaeti et al. (2014)

Where e is Euler's exponential constant (2.71828). 
To investigate the existence of acceleration, deceleration or stagnation or stagnation in growth rate of agricultural investments and output growth, quadratic equation in time variables was fitted to the data for the two periods following (Onyenweaku and Okoye, 2005); Akpaeti et al. (2013) as follows:

$\log Q=a+b t+c t^{2}$

In specification above, both the linear and quadratic time terms give a secular path to the dependent variable $(\mathrm{Q})$. The quadratic time term $\mathrm{t}^{2}$ allows for the possibility of acceleration or deceleration or stagnation in growth during the period of the study. Significant positive value of the coefficient of $t^{2}$ confirms significant acceleration in growth, significant negative value of $t^{2}$ confirms significant deceleration in growth while non-significant coefficient of $t^{2}$ implies stagnation or absence of either acceleration or deceleration in the growth process for the three periods.

\section{RESULTS AND DISCUSSION}

\subsection{Unit Root Test Result}

The results of Augmented Dicker Fuller $(A D F)$ a unit root tests are presented in Table 1. Results revealed that agricultural investment (AGINV) variable was not stationary at levels but at first difference, therefore integrating in the order of $1\{$ i.e, $1(1)\}$ for both intercept, intercept and trend specifications. While agricultural output growth was stationary at levels.

Table-1. Results of Unit root test

\begin{tabular}{|c|c|c|c|c|c|}
\hline \multirow{2}{*}{$\begin{array}{l}\text { Variables } \\
\text { (logged) }\end{array}$} & \multicolumn{2}{|c|}{ Level } & \multicolumn{2}{|c|}{$1^{\text {st }}$ Difference } & \multirow[t]{2}{*}{ Conclusion } \\
\hline & Intercept & $\begin{array}{c}\text { Trend + } \\
\text { Intercept }\end{array}$ & Intercept & $\begin{array}{c}\text { Trend + } \\
\text { Intercept }\end{array}$ & \\
\hline AGINV & $-1.701[0]$ & $-1.157[0]$ & $-5.890[0]^{* * *}$ & $\begin{array}{c}- \\
6.161[0] * * *\end{array}$ & $I(1)$ \\
\hline AGRGDP 1 & $-6.039[0]^{* * * *}$ & $-5.972[0] * * *$ & ------ & $-\cdots$ & $I(O)$ \\
\hline
\end{tabular}

Source: Computed from Central Bank of Nigeria $(\mathrm{CBN})$ data of various years. $* * *=1 \%$ level. The values in bracket [ ] for the ADF test shows the optimal lag length selected by the SIC within a maximum lag of 9 .

\subsection{Cointegration Test}

With the variable (agricultural investment) became stationary at first difference and integrated of order $1\{$ i.e, $1(1)\}$ except for agricultural output growth, another test was carried out to examine the existence of a co-integrating relationship between the non-stationary variables using Johansen cointegration tests are presented in Tables 2 and 3 respectively. The results of both the Trace and the Maximum Eigen value tests indicates the presence of co-integrating relationship the two variables. This reveals that there is evidence of a long-run relationship between these variables in Nigeria. 
Table-2. Johansen Cointegration Trace Test

\begin{tabular}{l|l|l|l}
\hline Null Hypothesis & $\begin{array}{l}\text { Alternative } \\
\text { Hypothesis }\end{array}$ & Test Statistic & Critical Value \\
\hline $\mathrm{r}=0$ & $\mathrm{r}=<1$ & 21.631 & $15.495^{* * *}$ \\
\hline $\mathrm{r}=1$ & $\mathrm{r}=<2$ & 3.281 & $3.842^{* *}$ \\
\hline
\end{tabular}

Source: Computed from Central Bank of Nigeria $(\mathrm{CBN})$ data of various years. $\mathrm{r}=$ number of co-integrating vector. ****,** are the significance levels at $1 \%$ and $5 \%$ respectively. P-values are obtained using response surfaces in MacKinnon et al. (1999).

Table-3. Johansen Cointegration Maximum Eigenvalue Test

\begin{tabular}{l|l|l|c}
\hline Null Hypothesis & $\begin{array}{l}\text { Alternative } \\
\text { Hypothesis }\end{array}$ & Test Statistic & Critical Value \\
\hline $\mathrm{r}=0$ & $\mathrm{r}=<1$ & 21.631 & $15.495^{* * *}$ \\
\hline $\mathrm{r}=1$ & $\mathrm{r}=<2$ & 3.281 & $3.842^{* *}$ \\
\hline
\end{tabular}

Source: Computed from Central Bank of Nigeria $(\mathrm{CBN})$ data of various years. $\mathrm{r}=$ number of co-integrating vector. ****,** are the significance levels at $1 \%$ and $5 \%$ respectively. P-values are obtained using response surfaces in MacKinnon et al. (1999).

\subsection{Growth Rate of Agricultural Investments}

The result of the trend analysis of agricultural investments in Nigeria is presented in Table 4. The result shows that agricultural investments had a positive trend in pre-financial sector reforms period and the financial sector reforms period. The coefficient of the trend variable was positive and highly significant at one percent in the two periods. This implies that time trend accounted for one percent level of the aggregate level of agricultural investments. The positive trend suggests a positive and increasing relationship between time and agricultural investment in the two periods. This result is an indication that the financial sector reforms have the capability of stimulating agricultural investments in Nigeria in spite of the economy's dependence on oil.

F-ratio for agricultural investments was significant at one percent for both pre-financial sector reforms (1970-1986) and the financial sector reforms (1987-2009) periods. This implies that the estimated parameters in the model were highly significant with respect to the dependent variables. $\mathrm{R}^{2}$ indicated that the estimated parameters in the variable had good fits as it explained the amount of variation in the dependent variable that was determined by the independent variable in the model.

Table-4. Estimated Trend Equations for Agricultural Investments

\begin{tabular}{l|l|l|l|l|l}
\hline $\begin{array}{l}\text { Dependent Variable/ } \\
\text { Period }\end{array}$ & $\begin{array}{l}\mathbf{B}_{\text {o }} \\
\text { (Constant) }\end{array}$ & $\mathbf{B}_{\text {1(Slope) }}$ & $\mathbf{R}^{2}$ & $\mathbf{R}^{-2}$ & F-Ratio \\
\hline Agricultural Investment & & & & & \\
\hline $\begin{array}{l}\text { Pre-Financial Sector } \\
\text { Reforms }\end{array}$ & $\begin{array}{l}2.510 \\
(16.345)^{* * * *}\end{array}$ & $\begin{array}{l}0.318 \\
(21.219)^{* * *}\end{array}$ & 0.968 & 0.966 & $450.267^{* * *}$ \\
\hline Financial Sector Reform & $\begin{array}{l}4.509 \\
(6.477)^{* * * *}\end{array}$ & $\begin{array}{l}0.207 \\
(8.844)^{* * * *}\end{array}$ & 0.788 & 0.778 & $78.217^{* * * *}$ \\
\hline
\end{tabular}

Source: Computed from Central Bank of Nigeria (CBN) data of various years. $* * *=1 \%$ significant levels. 
Table 5 shows the growth rates of agricultural investments for the two periods under consideration. Agricultural investments had a positive growth rate of 37.44 percent in the prefinancial sector reforms period and 23.00 percent in the financial sector reforms period. The growth rate of 37.44 in the pre-financial sector reforms period was higher than 23.00 in the financial sector reforms period. This shows that financial sector reforms might have increased agricultural investments in the pre-financial sector reforms period than the financial sector reforms period by attracting investors into the agricultural sector though the growth rates between the two periods were not statistically significant at 5 percent $\left(\mathrm{t}_{\text {cal }}<\mathrm{t}_{\text {tab }}\right.$ at $\left.\mathrm{P}=0.5\right)$. The positive growth rate in the pre-financial sector reforms period was an indication that there might have been genuine investors who were still interested and investing in agricultural sector in spite of the heavy dependence of the economy on oil. According to Ekpo and Umoh (2000), revenue from oil represented almost 90 percent of foreign exchange earnings and 85 percent of total exports. Though the oil boom afforded government the much needed revenue, it also created serious structural problems in the economy that gave rise to a comprehensive financial sector reforms in 1987.

Table-5. Growth Rates of Agricultural Investments

\begin{tabular}{l|l}
\hline Dependent Variable/ Period & Growth Rates in Percentages \\
\hline Agricultural Investments & \\
\hline Pre-Financial Sector Reforms & 37.44 \\
\hline Financial Sector Reforms & 23.00 \\
\hline
\end{tabular}

Source: Computed from Central Bank of Nigeria (CBN) data of various years.

To determine whether there was acceleration, deceleration or stagnation in the movement in growth rates of agricultural investments in the two periods, a quadratic equation was estimated in time variables. Table 6 indicated that the coefficient of time variables was significantly negative at 1 percent confirming deceleration in growth of agricultural investment in the two periods under consideration. This implies that financial sector reforms brought a decrease in growth of agricultural investments in the two periods in the study.

Table-6. Quadratic Equations in Time Variables for Agricultural Investments

\begin{tabular}{l|l|l|l|l|l|l}
\hline $\begin{array}{l}\text { Dependent Variable } \\
\text { / period }\end{array}$ & $\begin{array}{l}\mathbf{B}_{\mathbf{o}} \\
(\text { Constant) }\end{array}$ & $\mathbf{B}_{1}$ (Slope) & $\mathbf{B}_{2}$ & $\mathbf{R}^{2}$ & $\mathbf{R}^{-2}$ & F-Ratio \\
\hline Agricultural Investments & & & & & & \\
\hline $\begin{array}{l}\text { Pre-Financial Sector } \\
\text { Reforms }\end{array}$ & $\begin{array}{l}2.125 \\
(9.569)^{* * *}\end{array}$ & $\begin{array}{llll}0.440 \\
(7.743)^{* * *}\end{array}$ & $\begin{array}{l}-0.007 \\
(-2.205)^{* *}\end{array}$ & 0.882 & 0.730 & $285.501^{* * *}$ \\
\hline Financial Sector Reform & $\begin{array}{l}-3.899 \\
(-1.672) * * *\end{array}$ & $\begin{array}{l}0.816 \\
(4.938) * * *\end{array}$ & $\begin{array}{l}-0.010 \\
(-3.709) * * *\end{array}$ & 0.965 & 0.862 & $69.751^{* * *}$ \\
\hline
\end{tabular}

Source: Computed from Central Bank of Nigeria $(\mathrm{CBN})$ data of various years. $* * * *$ and $* *=1$ and $5 \%$ significant levels respectively.

\subsection{Growth Rate of Agricultural Output}

Table 7 shows the result of the trend analysis of agricultural output. From the result, agricultural output exhibited a positive trend in the two periods (pre-financial sector reforms 
period and the financial sector reforms period) in the study. The coefficient of the trend variable was positive and highly significant at one percent in the two periods. This implies that time trend accounted for one percent level of the aggregate level of agricultural output in the analysis. The positive trend suggests that there is a positive and increasing relationship between time and agricultural output in the study periods. This result is an indication that the financial sector reforms stimulated agricultural investments which culminated in growth in the agricultural sector.

The table revealed that the F-ratio for agricultural output was significant at one percent for both pre-financial sector reforms (1970-1986) and the financial sector (1987-2009) periods. This indicates that the estimated parameters in the model were highly significant with respect to the dependent variables. $\mathrm{R}^{2}$ indicated that the estimated parameters in the variable had good fits as the variation in the dependent variable was indicated by the independent variable in the model. The result of the growth rates for agricultural output is presented in Table 8 . The table revealed that the growth rates of output in agriculture were both positive at 30.47 percent in the prefinancial sector reforms period and 7.04 percent in the financial sector reforms period. The growth rate of 30.47 in the pre-financial sector reforms period was higher than 7.04 percent in the financial sector reforms period. However, the growth rates between the two periods were not significantly different at 5 percent $\left(\mathrm{t}_{\mathrm{cal}}<\mathrm{t}_{\text {tab }}\right.$ at $\left.\mathrm{P}=0.5\right)$. This implies that financial sector reforms might have favoured agricultural output in the pre-financial sector reforms period than the financial sector reforms period though the growth rates between the two periods were not statistically significant at 5 percent and is similar to that of agricultural investments. This is an indication that there might have been genuine investors who were still investing in agricultural sector which resulted in output growth in the sector in spite of the heavy dependence of the economy on oil.

Since acceleration, deceleration or stagnation has to do with the movement in growth rates of agricultural output in the two periods, to ascertain whether the growth rates were increasing, decreasing or stagnant, a quadratic equation was estimated in time variables of output in agriculture as shown in table 9. The result revealed that there was non-significant value of the coefficient of time variables of output in agricultural growth suggesting stagnation or absence of either acceleration or deceleration in the growth process of agricultural output in the pre-financial sector reforms period while there was significant positive value of the coefficient of the time variables of output in agricultural growth confirming significant acceleration at one percent in growth in the financial sector reform period. This implies that financial sector reforms brought about an increase in growth of agricultural output.

Table-7. Estimated Trend Equations for Agricultural Output

\begin{tabular}{l|l|l|l|l|l}
\hline $\begin{array}{l}\text { Dependent Variable/ } \\
\text { period }\end{array}$ & $\begin{array}{l}\mathbf{B}_{\mathbf{o}} \\
\text { (Constant) }\end{array}$ & $\mathbf{B}_{\text {1(Slope) }}$ & $\mathbf{R}^{2}$ & $\mathbf{R}^{-2}$ & F-Ratio \\
\hline Agricultural Output & & & & & \\
\hline $\begin{array}{l}\text { Pre-Financial Sector } \\
\text { Reforms }\end{array}$ & $\begin{array}{l}6.874 \\
(26.123)^{* * *}\end{array}$ & $\begin{array}{l}0.266 \\
(10.348)^{* * *}\end{array}$ & 0.877 & 0.869 & $107.099^{* * *}$ \\
\hline Financial Sector Reform & 9.813 & 0.068 & 0.920 & 0.916 & $241.566^{* * *}$ \\
\hline
\end{tabular}




\begin{tabular}{|c|c|}
\hline$(75.556)^{* * * *}$ & $(15.542)^{* * *}$ \\
\hline \multicolumn{2}{|c|}{ Source: Computed from Central Bank of Nigeria $(\mathrm{CBN})$ data of various years. $* * *=1 \%$ significant levels. } \\
\hline \multicolumn{2}{|c|}{ Table-8. Growth Rates of Agricultural Output } \\
\hline Dependent Variable/ Period & Growth Rates in Percentages \\
\hline \multicolumn{2}{|l|}{ Agricultural Output } \\
\hline Pre-Financial Sector Reforms & 30.47 \\
\hline Financial Sector Reforms & 7.04 \\
\hline
\end{tabular}

Source: Computed from Central Bank of Nigeria (CBN) data of various years.

Table-9. Quadratic Equations in Time Variables for Agricultural Output

\begin{tabular}{l|l|l|l|l|l|l}
\hline $\begin{array}{l}\text { Dependent } \\
\text { Variable/ } \\
\text { Period }\end{array}$ & $\begin{array}{l}\mathbf{B}_{\mathbf{o}} \\
\text { (Constant) }\end{array}$ & $\mathbf{B}_{1}$ (Slope) & $\mathbf{B}_{2}$ & $\mathbf{R}^{2}$ & $\mathbf{R}^{-2}$ & F-Ratio \\
\hline Agricultural Output & & & & & & \\
\hline $\begin{array}{l}\text { Pre-Financial Sector } \\
\text { Reforms }\end{array}$ & $\begin{array}{l}7.133 \\
(16.487) * * *\end{array}$ & $\begin{array}{l}0184 \\
(1.660)\end{array}$ & $\begin{array}{l}0.005 \\
(0.763)\end{array}$ & 0.882 & 0.865 & $52.343^{* * *}$ \\
\hline $\begin{array}{l}\text { Financial Sector } \\
\text { Reform }\end{array}$ & $\begin{array}{l}11.651 \\
(31.062) * * *\end{array}$ & $\begin{array}{l}-0.065 \\
(-2.459) * *\end{array}$ & $\begin{array}{l}0.002 \\
(5.043) * * *\end{array}$ & 0.965 & 0.961 & $274.008^{* * *}$ \\
\hline
\end{tabular}

Source: Computed from Central Bank of Nigeria $(\mathrm{CBN})$ data of various years. $* * *$ and $* *=1$ and $5 \%$ significant levels respectively.

\section{CONCLUSION AND RECOMMENDATIONS}

The Nigerian government has promoted several policies over the years with the aim of increasing investments and output growth in the agricultural sector. This study established that growth in agricultural investments and output were not significantly different between the prefinancial sector reforms period and the financial sector reforms period. This implies that the growth rates were the same though the financial sector reforms might have favoured agricultural investments and output growth in the pre-financial sector reforms period than in the financial sector reforms period in Nigeria. This is an indication that the financial sector reforms have the capability of stimulating agricultural investments which culminated in growth in the agricultural sector in Nigeria in spite of the economy's dependence on oil. Accordingly, the study concludes that the financial sector drives agricultural investments and output growth in the Nigeria. Hence, policies and sound regulatory framework that would enhance the development of a strong, healthy and dynamic financial system should be pursued. Such policies should be tailored towards the provision of sound infrastructures and macroeconomic stability that would create incentives for agricultural investment and growth of business opportunities on a sustainable basis and foster the expansion of financial institutions.

\section{REFERENCES}

African Economic Outlook, 2011. Nigeria 2011. Available from www.africaneconomicoutlook.org.

Akpaeti, A.J., N.E. Bassey and U.E. Okon, 2014. Trend evaluation of agricultural export crops in Nigeria. International Journal of Food and Agricultural Economics, 2(1): 165-175.

Akpaeti, A.J., A.C. Nwosu, J.C. Nwaru and V.O. Ebong, 2013. Econometric assessment of trend in loanable funds in Nigeria. The Journal of Economics. Photon, 113: 157-162. 
Asamoah, G.N., 2008. The impact of the financial sector reforms on savings. Investment and growth of gross domestic products (GOP) in Ghana. International Business and Economic Research Journal, 7(10): 73-84.

Central Bank of Nigeria, 2004. Finance, investment and growth in Nigeria. In: Nnanna, O. J., Englaina, A. and Odoko., F.O, Central Bank of Nigeria Publication, 1-2 1

Central Bank of Nigeria, 2010. Annual report. Available from www.cbn.gov.ng [Accessed 31 st December].

De Long, J.B. and L.W. Summers, 1993. How strongly do developing economies benefit from equipment investment. Journal of Monetary Economics, 32(3): 395-415.

Diao, X., S. Fan, S. Kanyarukiga and B. Yu, 2010. Agricultural growth and investment option for poverty reduction in Rwanda. Washington, DC 20006-1002 USA: Research Monograph of International Food Policy Research Institute Research. pp: 1-142.

Ekpo, H.A. and O.J. Umoh, 2000. An overview of economic growth and development. In: Ajaegba, A. I., B. J. Mathew-Daniel and O. E. Uya (eds). Nigeria Ppeople united, a future assured. A compendium. Lagos, Nigeria: Gabumo Publishing Co, Ltd. pp: 125.

Emenuga, C., 1996. The outcome of financial sector reforms in West Africa: 14-17. Available from www.Idre.com.

Food and Agricultural Organisation, 2000. Global issues for sustainable agriculture. A Report for the World Commission on Environment and Development.

Haque, I.U., 1995. The macroeconomic environment and competitiveness. In: Haque, I.U., Martin Bell, Dahlman, C, Sanjaya, L and Keith Pavitt, eds. Trade, technology and international competiveness. Washinton, D.C.: The World Bank.

Johansen, S., 1988. Statistical analysis of cointegration vector. Journal of Economic dynamics and Control, 12: 231-254.

Johansen, S., 1991. Estimation and hypothesis of cointegration vectors in Gaussian vector autoregressive model models. Econometrica, 59: 1551-1580.

Klenow, P. and A. Rodriguez-Clare, 1997. The neoclassical revival growth economics. Had it gone too far? In: Ben Bernanke and Julio Rotemberg (eds). NBER macroeconomics annual 1997. Cambridge, Mass: MIT Press.

Kolawole, B.O., 2013. Institutional reforms, interest rate policy and the financing of the agricultural sector in Nigeria. European Scientific Journal, 9(12): 259-272.

MacKinnon, J.G., A.A. Haug and L. Michelis, 1999. Numerical distribution functions of likelihood ratio tests for cointegration. Journal of Applied Econometrics, 14: 563-577.

Maddala, G.S., 2002. Introduction to econometrics. New Delhi India: John Wiley and Sons.

Mang, H.G., 2009. Politics and economics of FADAMA irrigation and product sales in the mining areas of the Jos Plateau in Nigeria. Draft Paper for WOW Working Group on the Politics of Land, Authority and National Resources.

Marjit, S., 2004. Financial sector reform for stimulating investment and economic growth- The Indian experience. Report Paper prepared for Asian Development Bank by Centre for Studies in Social Sciences, Calcutta, India. pp: 1-21.

Nwosu, A.C., 2004. Private sector initiatives in agricultural development in Nigeria. In: Nnanna,O.J; Okafor, C.M. and Odoko, F.O. (eds). Central bank of Nigeria. Proceedings of the Thirteenth Annual 
Conference of the Regional Research Unit, Theme: Enhancing Private Sector-Led Growth in Nigeria Held at motel Benin Plaza, Benin City, oEdo State.8-12th November, 2004.

Nwosu, A.C. and O. Ogunfowora, 1977. An appraisal of capital investment in some farming communities in Kwara State of Nigeria. NJESS, 19(3): 387-401.

Obadan, M.I. and A.F. Odusola, 2001. Savings, investment and growth patterns in developed and deveoping countries. National Centre for Economic Management and Administration (NCEMA), Ibadan, Nigeria. Monogragh Series, No. 1: 3-8.

Okoye, B.C., C. Asumugha, L.T. Okezie and C.E. Onyenweaku, 2008. Econometric assessment of the trend in cocoyam production in Nigeria, 1960/61-2003/2006. Medwell Agricultural Journal, 3(2): 99-101.

Onyenweaku, C.E. and B.E. Okoye, 2005. Trends in cassava output, area and productivity in Nigeria, 1960/61-2003/04. Proceedings of the 39th Conference of the Agricultural Society of Nigeria, Benin.

Romer, P., 1986. Increasing returns and long-run growth. Journal of Political Economy, 94(5): 1002-1037.

Serven, L. and A. Solimano, 1993. Striving for growth after adjustment: The role of capital formation. Washington, D.C.: The World Bank.

Singh, A., 1996. Saving, investment and the corporation in the East Asian Miracle. Project on East Asian development: Lessons for a new global environment, study 9. Geneva:United Nations Conference on Trade and Development (UNCTAD).

Soyibo, H. and F. Adekanye, 1992. Financial system regulation, deregulation and savings mobilization in Nigeria. African Economic Research Consortium Research Paper II.

Usman, N.E., 2006. Agriculture: Vital to Nigerian economic development. Paper Presented at the Forum of Econommic Stakeholders on Growing the Nigerian Economy. Thisday Newspaper, July 25.

World Bank, 1993. The East Asian miracle: Economic: Economic growth and public policy. New York: Oxford University Press.

World Bank, 1998. Development indicators. Washington, D. C. 